\title{
Periodontal Surgery for Correction of Gingival Smile: a Case Report Analysis of Periodontal Parameters After 2 Years
}

\author{
Cirurgia Periodontal para Correção de Sorriso Gengival: Relato de Caso e Análise dos \\ Parâmetros Periodontais Após 2 Anos
}

\author{
Marcelo Yudi Sakamotoa; Mariana Oliveiraa; Nayara Flores Macedob; Humberto Osvaldo Schwartz-Filho*a \\ ${ }^{a}$ Federal University of Paraná, Departament of Stomatology. PR, Brasil. \\ bPontifical Catholic University of Paraná, Graduate Program in Dentistry. PR, Brasil. \\ *E-mail: betoschwartz@ufpr.br \\ Recebido em: 06/10/2020 \\ Aprovado em: 09/12/2020
}

\begin{abstract}
Gingival smile is a term used to describe an aesthetic condition in which excessive gingival exposure at the jaw level occurs during smile. There are several factors related to its etiology, the most common is the altered passive eruption of anterior superior teeth. To correct this disharmony, a multidisciplinary approach is necessary, and the treatment plan depends on a correct diagnosis and assessment for a better prognosis. The present study aims to describe a clinical case where periodontal surgical techniques were used to correct this condition. Female patient, 25 years old, with aesthetic complaint of the amount of gum exposed when smiling and diagnosed with altered passive eruption. Clinical crown augmentation surgery was performed on the anterior superior teeth. After 1 and 2 years, periodontal clinical parameters (probing bleeding, probing depth, clinical attachment level, crown length, keratinized mucosa width and plaque index) were reassessed, through clinical examination, digital photographic monitoring and measurement tools. In two years, it was possible to note the stability of the results achieved, maintaining values similar to those of the immediate postoperative period. The case report confirmed the success of the clinical crown augmentation surgery and the periodontal parameters stability evaluated after 2 years.
\end{abstract}

Keywords: Periodontics Surgery. Gingivectomy. Aesthetics.

\section{Resumo}

Sorriso gengival é o termo utilizado para descrever uma condição estética em que ocorre uma exposição gengival excessiva ao nível da maxila, durante o sorriso. Há diversos fatores relacionados a sua etiologia, sendo a mais comum a erupção passiva alterada dos dentes ântero-superiores. Para correção dessa desarmonia é necessária uma abordagem multidisciplinar, sendo o plano de tratamento dependente de um correto diagnóstico e avaliação para um melhor prognóstico. O presente estudo tem objetivo de descrever um caso clínico onde técnicas cirúrgicas periodontais foram utilizadas para correção dessa condição. Paciente gênero feminino, 25 anos de idade, com queixa estética da quantidade de gengiva exposta ao sorrir e com diagnóstico de erupção passiva alterada. Foi submetida a cirurgia de aumento de coroa clínica nos dentes antero-superiores. Após 1 e 2 anos foram reavaliados os parâmetros clínicos periodontais (sangramento a sondagem, profundidade de sondagem, perda de inserção, comprimento da coroa, largura da mucosa queratinizada e índice de placa), através de exame clinico, acompanhamento digital fotográfico e ferramentas de medição de imagem. Em dois anos, foi possivel constatar a estabilidade dos resultados alcançados, mantendo valores semelhantes aos do pós-operatório imediato. O relato de caso confirmou o sucesso da cirurgia de aumento de coroa clínica e a estabilidade dos parâmetros periodontais avaliados após 2 anos.

Palavras-chave: Periodontia. Cirurgia. Gengivectomia. Estética.

\section{Introduction}

Aesthetics is an important part of dentistry. Therefore, it is crucial to work with full knowledge of the biological principles that guide it, in order to harmonize the face and smile, as well as maintain periodontal health through the biofilm control and attention to periodontal supportive therapy. Periodontology is the specialty of dentistry that seeks solutions in the facial aesthetics construction, in which the harmony among lips, teeth and gums is extremely important ${ }^{1}$.

The gingival margins relation of the maxillary anterior teeth plays an important role in the aesthetic appearance of the teeth crowns ${ }^{2}$. An attractive smile usually presents a coincidence of disposition between the incisal edges of the anterior superior teeth and the lower lip curvature ${ }^{3}$. In addition, during smile, the upper lip must be positioned at the level of the gingival margin of the upper central incisors, so that it is considered more harmonious. The crowns of these teeth are covered by 1 to $3 \mathrm{~mm}$ of inserted gum, -emphasizing the interdental gingiva. As well as the free gingiva edge around the cervical teeth margin and should be evident ${ }^{4}$.

Gingival smile is the term used to describe a relatively frequent non-aesthetic condition, characterized by excessive gingival exposure at the jaw level, during smile ${ }^{5}$. The smile height is influenced by sex and age. There is evidence that women have higher smiles than men and that dentogingival exposure decreases with age. Therefore, some amount of gum on display is aesthetically acceptable and, as mentioned in the literature, provides for a youthful appearance ${ }^{6}$. There is no consensus as to the amount of gum that must be exposed to consider a smile as gingival, however, the values vary between 0 and $4 \mathrm{~mm}^{5}$, but when reaching $4 \mathrm{~mm}$ of gingival 
exposure, there is a non-aesthetic perception, both by clinical dentists and general population.

The excess of gingival tissue does not only cause aesthetic problems, but also functional problems, such as decreased protection from the masticatory function trauma and even contributing to periodontal disease, due to the gingival excess that can lead to the formation of false periodontal pockets that will collaborate in the inflammatory process maintenance and hinder hygiene ${ }^{8}$. In addition, several behavioral and psychological changes are found in patients with a gingival smile, including shyness, impaired self-esteem, and other forms of social restriction? .

Different therapeutic modalities are indicated for the gingival smile treatment depending on its etiology ${ }^{10}$. The most common etiology found is the altered passive eruption (APE) ${ }^{5}$, in which the periodontium does not migrate satisfactorily in the apical direction, thus covering the cementoenamel junction (CEJ), resulting in a diminished clinical crown and a smile considered to be childlike ${ }^{11}$. By cosmetic crown augmentation surgery performed by gingivectomy or flap positioned apically with or without osteotomy ${ }^{12}$. APE is classified into two types: type 1 is defined by the gingival margin being incisal or occlusal for the CEJ, where there is a visible wider band of gingiva inserted from the gingival margin to the mucogingival junction than the generally accepted width of $3.0-4.2 \mathrm{~mm}$ in the maxilla and 2.5 to $2.6 \mathrm{~mm}$ in the mandible. The mucogingival junction is usually apical to the alveolar crest in these cases. Type 2 which is defined by the presence of a gingival band adhered from the gingival margin to the mucogingival junction which appears to be within the normal average width, as specified above. However, in this type of altered passive eruption, the entire inserted gingiva is located in the anatomical crown, with the mucogingival junction located at the CEJ level ${ }^{13}$.

The purpose of this case report was to accompany a patient with a complaint of the amount of gingiva exposed when smiling, from planning to the performance of clinical crown augmentation surgery. Aiming to return aesthetics, as well maintenance of periodontal health. In addition, two years follow up was carried to confirm the success and stability of the periodontal parameters.

\section{Case Report}

A female patient, 25 years old attended the Federal University of Paraná clinic for dental evaluation with an aesthetic complaint reporting that her smile "showed a lot of gums". The patient's consent, authorizing the procedure and the case documentation, was obtained via an informed consent form. All procedures were performed following respect for the patient's privacy, data confidentiality and human dignity. Anamnesis, clinical examination and a complete periodontal examination was performed including: bleeding on probing, probing depth, clinical attachment level, crown length, keratinized mucosa width and plaque index. Probing depth ranging from 1 to $2 \mathrm{~mm}$ in all sites, and a wide range of keratinized mucosa was observed. After the examination it was confirmed that the patient had a healthy periodontal condition. From the exams, the presence of upper anterior teeth with short clinical crows and excess gingival tissue was found and the diagnosis was APE (Figure 1).

Figure 1 -Presence of upper anterior teeth with short clinical crows and excess gingival tissue

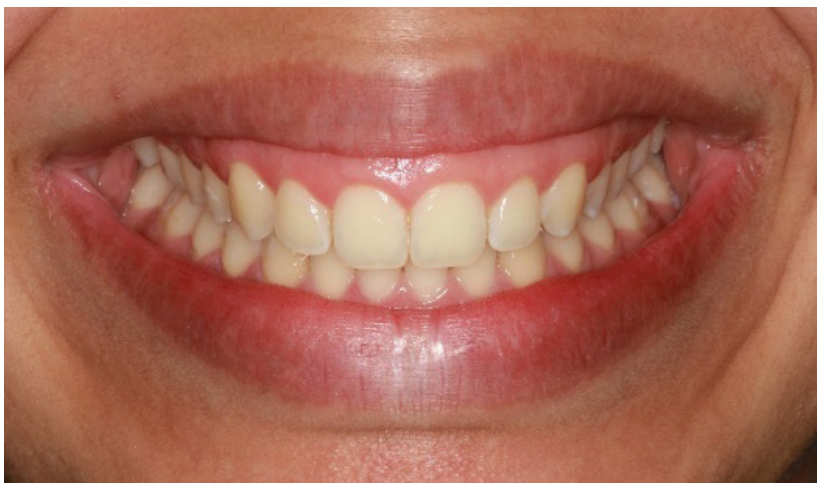

Source: The authors.

After biofilm control and obtaining plaster models, digital planning using photographs was carried out. During this stage, frontal facial observation is essential, while the patient smiles, allowing to evaluate the dental and facial midline position of the smile, the type of dominant musculature, curvature, oral corrector and the size of the gingival exposure, which indicate the degree of smile influence. Intraoral and extraoral photographs of the patient at rest, smiling and bilateral profile were taken ${ }^{14}$.

The digital planning was carried out with the program ImageJ 1.5Oi (National Institutes of Health, Public domain) where measurements were obtained, in millimeters, of each region subject to surgery (Figure 2). At this point it was possible through a calibration of measurements in the image using the real size of the teeth in the plaster model. Measurements of the gingival margin in relation to the lip and measurements in relation to the height of the tooth margins were perfomed. Such measures indicated exactly the ideal positions of the gingival margin after surgery.

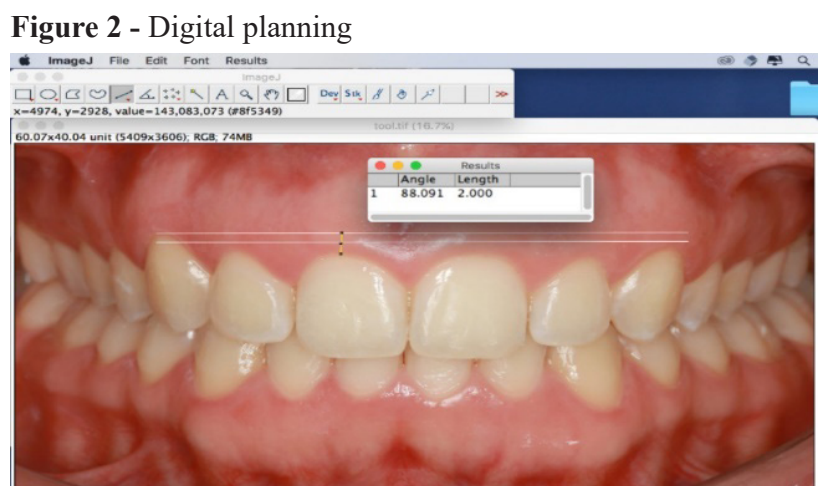

Source: The authors.

Once digital planning was carried out, the measurements were transferred to the plaster model with the help of a dry point compass. Na acetate surgical guide was then made in order to facilitate decision making during surgery. It was cut according to the measures obtained, its use promotes greater safety in the performance of gingivectomy because it was possible to visualize the limits of the incision more clearly and 
thus reduce the margin of errors by optimizing clinical time.

After anesthesia with 2\% Mepivacaine, guide was placed in the position, then the region to be incised was delimited with the scalpel, the internal bevel incision was made, bypassing the cervical margin of the guide acetate, creating a soft tissue collar, After that, a full thickness flap was performed, the guide was removed and intra-sulcular incisions were made in order to release this gingival tissue collar, which was removed with Goldman-Fox curettes. With the removal of the collar, the use of the Molt detacher allowed exposing bone tissue and, thus, using a periodontal probe, the bone crest could be observed, positioning $1 \mathrm{~mm}$ from the CEJ. It is known that to reestablish the necessary distances for a reinsertion of connective tissue, ensuring the correct biological space repositioning, the bone crest must be repositioned $2 \mathrm{~mm}$ apical from the position of the intended gingival margin ${ }^{15}$. Therefore, it was necessary to perform osteotomy and osteoplasty, using an Ochsenbein chisel. During osteotomy, there was a concern with the zeniths formation of the gingival margins of each element involved in the surgery. With the distances to the inserted structures reestablished, the surgery was completed with the suspension technique suture (Nylon 5-0) (Figure 3).

Figure 3 A - Guide in position, B - Gingival tissue collar, C/D - Collar removal, E - measurement between bone crest and cementoenamel junction, F - Osteotomy and osteoplasty using Ochsenbein chisel and G - Immediate post operative

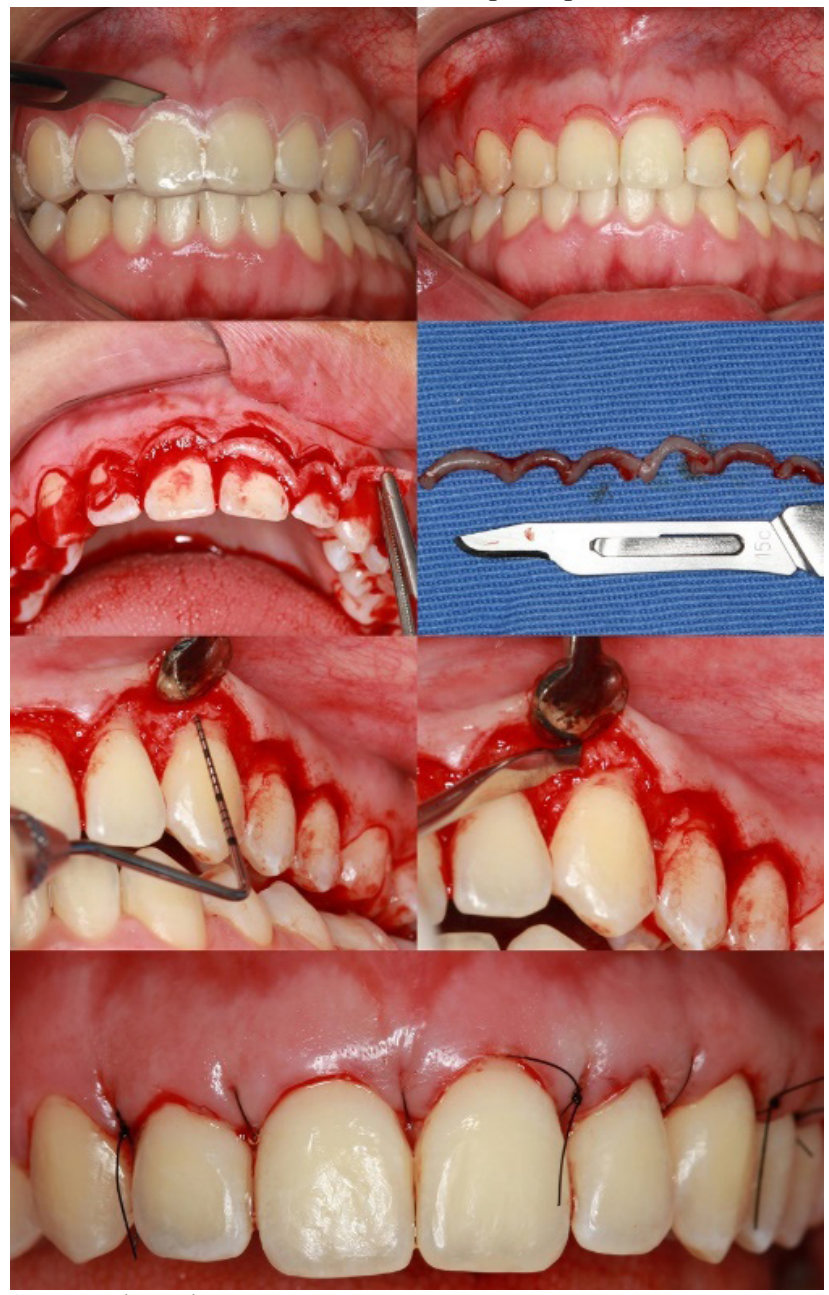

Source: The authors.
Post-operative medication consisted of Nimesulide $100 \mathrm{mg}$ and Paracetamol $750 \mathrm{mg}$ for seven and two days, respectively. For mouthwash, $0.12 \%$ Chlorhexidine Digluconate was performed for 15 days. After 7 days the sutures were removed and the postoperative follow-up continued after 30 days, 1 and 2 years.

On the return of 1 and 2 years, clinical examination was repeated evaluating periodontal clinical parameters (bleeding on probing, probing depth, clinical attachment level, crown length, keratinized mucosa width and plaque index). In addition, a new photographic documentation was performed (Figure 4).

Figure 4 - Two-year follow-up

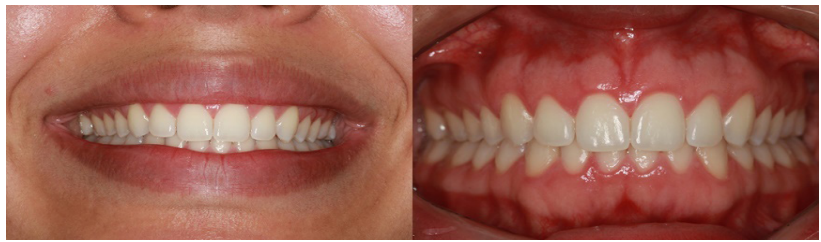

Source: The authors.

The plaster models were made in order to be used as a scale to measure in the photographic records using the tools of the IMAGE J 1.5Oi program (National Institutes of Health, Public domain). The distance in the image was calibrated in Image $\mathrm{J}$ by the actual measurement found in the model. The mesio-distal distance from the upper right central incisor at the contact point was used as a reference. Teeth 15 to 25 were evaluated, to measure the crown length, the teeth central line was used in the cervical occlusion and the keratinized mucosa width was measured through the most apical portion of the gingival margins to the mucogingival line.

The results, obtained in millimeters, of the clinical crown length and the keratinized mucosa, were organized in the form of a graph, comparing preoperative values, immediate postoperative and one and two years after surgery.

\subsection{Results and Discussion}

During the post-surgical follow-up, it is possible to observe the harmony restoration among teeth, lips and gums with periodontal health characteristics present (pink color, battlements filled entirely by the papillae and "orange peel" aspect). In addition, it was possible to verify the patient's satisfaction with the result of the surgery, exceeding her expectations.

Regarding the clinical crowns length, it can be observed that during the post-immediate period there was an increase in the clinical crowns length due to the gingival collar removal during surgery.

After one year, a gingival increase was observed at the central incisors region, probably associated with an inflammatory process due to the plaque accumulation. In two years, it was possible to note the stability of the results achieved with the clinical crown augmentation surgery, maintaining 
values similar to those of the immediate postoperative period, with greater variations in tooth 21 where there was a gingival increase and in tooth 12 where there was a slight note gingival recession. (Figure 5).

Figure 5 - Graph with clinical crown length pre op., 0, 1 and 2 years.

\section{Length of the clinical crown}

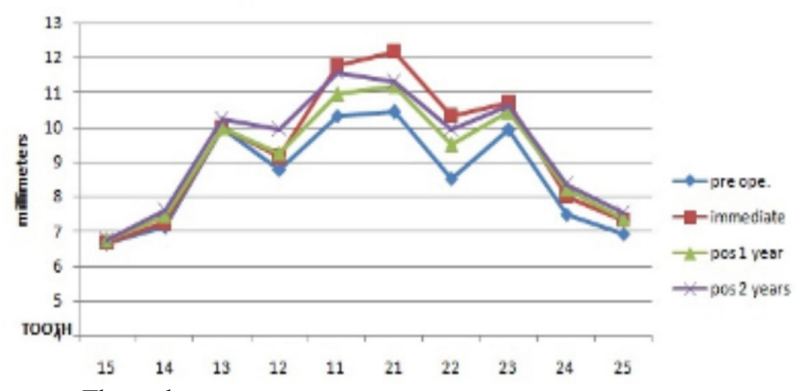

Source: The authors.

The amount of keratinized mucosa varied slightly over the years. The greatest variation was observed in tooth 21 , where there was an increase in the amount of keratinized mucosa, probably associated with an inflammatory process, as previously mentioned. (Figure 6).

Figure 6 - Graph with the keratinized mucosa length pre op., 0, 1 and 2 years

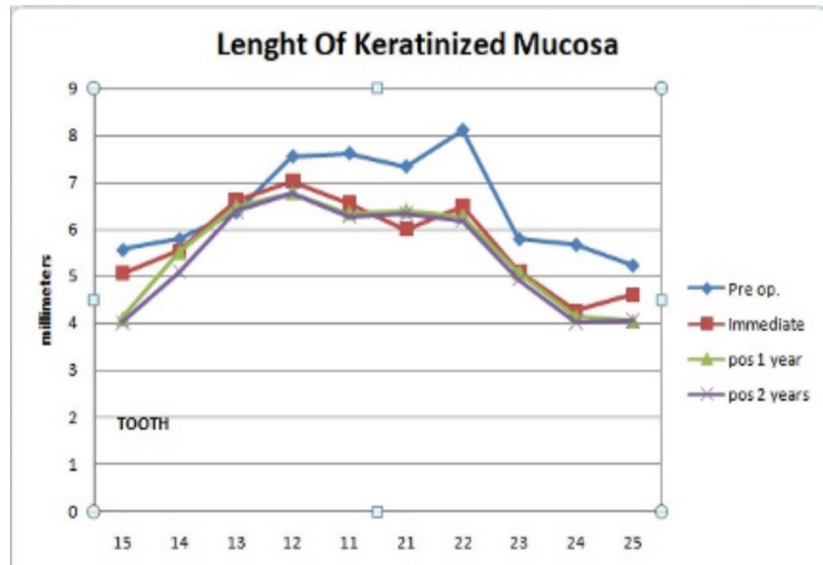

Source: The authors.

The probing depth varied between 1 and $2 \mathrm{~mm}$ in the evaluated teeth, during all the evaluated periods.

According to the literature there is an acceptable standard for a harmonic smile. Most professionals claim that this pattern is influenced by the dentogingival relation, in which the upper lip must be located at the same level as the gingival tissue margin of the upper central incisors. However, gingival exposure of up to $3 \mathrm{~mm}$ exceeding the cervical limits of the tooth structure during smile is still considered aesthetic and appropriate ${ }^{16}$.

One important factor discussed is the varied gingival smile etiology. Gingival growth, excess vertical growth, labial hyperactivity, short upper lip, dentoalveolar extrusion and altered passive eruption, are the different causes reported. Dental surgeon must have knowledge to guide the clinical examination and be trained to evaluate certain anatomical points, such as: interlabial distance at rest, the upper incisors exposure at rest and speech, the upper lip morpho functional characteristics, the teeth positioning, the dental axes alignment and the gingival contour limits. In addition, the use of digital tools, which has increased and becoming accessible, can facilitate the evaluation of these points, such as the use of photographs, which promotes a better aesthetic smile analysis, helps in determining the lips and soft tissues positioning during the smile dynamics ${ }^{17}$. These assessments are crucial for a differential diagnosis and the establishment of an appropriate treatment plan for each case ${ }^{18}$.

Included in the main gingival smile etiologies, there is the APE, which involves periodontal surgical techniques in its correction. Among them, the surgical technique to increase the clinical crown with immediate postoperative results ${ }^{19}$. In order to perform the clinical crown augmentation surgery, in this case, planning was necessary which involved several stages. Anamnesis, clinical examination and photographic record were performed to study the intervention. As a facilitator in carrying out the procedure, a surgical guide obtained from a study model was used. Based on the patient's smile and face analysis, it was possible to determine how many millimeters of gingival tissue removed from each anterior tooth in order to promote the desired harmony would be necessary.

Clinical crown augmentation surgery is an easy technique to perform and presents satisfactory results. However, knowledge about indications and good planning for its execution is fundamental to minimize possible postoperative complications, such as pain, gingival retraction, interproximal cracks opening, loss of gingival papilla, extreme clinical crowns prolongation and gingival inflammation predisposing to periodontal disease ${ }^{20}$. Omission in the gingival biotype evaluation, improper removal of the keratinized mucosa width and professional inexperience are examples of mistakes that must be avoided. Digital planning and use of a guide are tools that make surgery faster and more accurate, consequently reducing possible failures.

Understanding on the part of the patient regarding the biofilm control and the necessary care to provide adequate conditions for the performance of the procedure is extremely important. In this case the patient demonstrated adherence to treatment plan, and commitment was fundamental for the success from preparation to postoperative period.

It is clear that a correct approach is mandatory. Factors such as anamnesis, clinical and physical examination, etiology of this gingival condition and dialogue with the patient must be carefully considered in order to develop a correct diagnosis and an appropriate treatment plan.

\section{Conclusion}

This two-year follow-up case report confirms the success of the periodontal surgery for correction of gingival smile and the periodontal parameters stability. 


\section{References}

1- Storrer CLM, Valverde FKB, Santos FR, Deliberador TM. Treatment of gummy smile: Gingival recontouring with the containment of the elevator muscle of the upper lip and wing of nose. A surgery innovation technique. J Ind Soc Periodontol 2014;18(5):656-60. doi: 10.4103/0972-124X.142468

2- Kokich VO, Kiyak HA, Shapiro PA. Comparing the perception of dentists and lay people to altered dental esthetics. J Esthet Dent 1999;11(6):311- 10 .

3- Pascotto RC, Moreira M. Dental Treatment and Aesthetic Medicine. Integração da odontologia com a medicina estética e correção do sorriso gengival. RGO 2005;53(3):171-5.

4- Sousa CP, Garzon AC, Sampaio JEC.Estética periodontal: relato de um caso. Rev Bras Cir Periodontia 2003:262-7.

5- Pinto TB. Técnicas de correção do sorriso gengival. Lisboa: Universidade de Lisboa; 2016.

6- Seixas MR, Costa Pinto RA, Araújo TM. Checklist dos aspectos estéticos a serem considerados no diagnóstico e tratamento do sorriso gengival. Dental Press J Orthod 2011;16(2):131- 5 .

7- Pires CV. Procedimentos plásticos periodontais em paciente com sorriso gengival-Relato de caso. RPeriodontia 2010;20:48-53.

8- Prichard JF. Advanced periodontal disease: surgical and prosthetic management. Philadelphia, W.B. Saunders; 1966

9- Ottoni J, Magalhães LF. Cirurgia plástica periodontal e periimplantar. São Paulo: Artes Médicas; 2006.

10- Pedron IG, Utumi ER, Tancredi ARC, Perrella A, Perez FEG. Sorriso gengival: cirurgia ressectiva coadjuvante à estética dental. Rev Odonto 2010:87-95

11- Rossi R. Altered passive eruption and familial trait: A preliminary investigation. Int J Dent 2014. doi: https://doi. org/10.1155/2014/874092

12- Cairo F, Graziani F, Franchi L. Periodontal plastic surgeryto improve aesthetics in patients with altered passive eruption/ gummy smile: a case series study. Int J Dent 2012, 837658 doi: $10.1155 / 2012 / 837658$

13- Mele M, Felice P, Sharma P, Mazzoti C, Bellone P, Zucchelli. Esthetic treatment of altered passive eruption. Periodontology 2000 2018;27:1-19. doi: https://doi.org/10.1111/prd.12206

14- Colombo VL. Análise facial frontal em repouso e durante o sorriso em fotografias padronizadas: Parte II: Avaliação durante o sorriso. Rev Dental Press Ortodon Ortop Facial 2004:9(4):86-97.

15- Sato LYM. A importância do planejamento na reabilitação estética do sorriso pela cirurgia plástica periodontal: relato de caso. Rev. Hosp Univ Getúlio Vargas 2006;569-75.

16- Castro PHDF.Planejamento reverso na correção de sorriso gengival. Rev Periodontia 2010;20(3):42-6.

17- Morley J, Eubank J. Macroesthetic elements of smile design. J Am Dent Assoc 2001; 132:3945.

18- Fernández-González R, Arias-Romero J, Simonneau-Errando G. Erupción pasiva alterada. Repercusiones em la estética dentofacial. RCOE 2005;10(3):289302

19- Silva DB. Cirurgia plástica periodontal para otimização da harmonia dentogengival - relato de caso clínico. Braz J Health 2010:1(1):31-6.

20- Morley J, Eubank J. Macroesthetic elements of smile design. Dent Assoc 2001;132(1):39-45. 